Pierre Gaudreault MD FRCPC, Joanne Guay MD FRCPC, Odette Nicol, Claire Dupuis PH D

\title{
Pharmacokinetics and clinical efficacy of intrarectal solution of acetaminophen
}

Acetaminophen is frequently administered orally to children for its analgesic properties, although its potency has never been clearly evaluated in this population. In certain situations (patients vomiting or unconscious), acetaminophen has to be given rectally. However, the rectal absorption of suppositories is frequently erratic. We undertoak this study first, to measure the absorption of an aqueous solution of acetaminophen administered rectally. Secondly, we evaluated acetaminophen's postoperative analgesic effects in children aged 1 to 8 years old undergoing adenoidectomy and/or tonsillectumy and compared its efficacy to meperidine. Twenty children received $20 \mathrm{mg}^{\cdot \mathrm{kg}^{-1}}$ of acetaminophen at the time of induction of anaesthesia while 20 others received I $\mathrm{mg} \cdot \mathrm{kg}^{-1}$ of meperidine intramuscularly. Thirty-two patients required meperidine in the Recovery Room. There was no statistical difference between the patients who received acetaminophen (I8), and those who received meperidine (14). The absorption of acetaminophen was incomplete (peak serum concentration: $70.8 \mu \mathrm{mol} \cdot L^{-1}$ ) and delayed. We conctude that the rectal administration of acetaminophen at the induction of anesthesia results in incomplete and delayed absorption and does not prevent the occurrence of immediate postoperative pain in children undergoing adeno-tonsillectomy.

\section{Key words}

ANALGESICS: acetaminophen; ANALGESICS, NARCOTIC: meperidine; FHARMACOKINETICS: acetaminophen, rectal absorption.

From the Clinical Pharmacology and Toxicology Division of the Department of Pediatrics, and the Department of Anesthesia-Reanimation and Biochemistry of the Hospital Sainte-Justine, and the Department of Pediatrics and Anesthesia-Reanimation of the University of Montreal, Montreal, Quebec.

Address correspondence to: Dr. Gaudreault, Hộpital Sainte Justine, 3175 Chemin Côte Sainte-Catherine, Montreal, Quebec, H3T 1C5.

This study was supported in part by a grant from La Compagnie de Produits aux Consommateurs McNeil and by a grant from the Interservice Clubs Council of Montreal.
The oral administration of analgesic/antipyretic products is sometimes difficult in children. Either the child refuses to ingest the prorluct or is unable to take it because he is vomiting as is the case with gastroenteritis or following surgery. To circumvent this problem the rectal route may be used. However the absorption and bioavailability of acetaminophen suppositories can be erratic. ${ }^{1}$ In contrast, when an aqueous solution of acetaminophen is administered rectally the quantity absorbed was comparable to that following oral administration. ${ }^{2}$

In adults acetaminophen is a good analgesic, without significant respiratory or central nervous system depressant effects. ${ }^{3-6}$ This agent could be of great value as an analgesic agent for outpatient surgery in children. However there are very little data concerning the efficacy of acetaminophen as an analgesic agent in children.

Therefore we undertook this study to evaluate the pharmacokinetics of an intrarectal solution of acelaminophen and compare its analgesic effect with meperidine.

\section{Methods}

This double-blind prospective study was conducted on 40 children undergoing tonsillectomy and/or adenoidectomy. These children were healthy and between one and eight years old. Informed consent was obtained for each patient. Anaesthesia was the same for each patient. After induction with nitrous oxide (65 per cent), oxygen ( 33 per cent) and halothane ( 2 per cent), intravenous atropine was administered and the patient was intubated. Thereafter the patients were divided randomly into two groups. The patients in Group 1 received an intrarectal solution of 20 mg $\mathrm{kg}^{-1}$ of acetaminophen diluted in an equal volume of sterile water. The concentration of the acetaminophen solution was 0.4 per cent. The solution was administered through a $\# 8$ french catheter introduced six to eight centimeters into the rectal ampoula. Patients were administered $0.5 \mathrm{ml} \cdot \mathrm{kg}^{-1}$. None defecated prematurely after the administraton of the acetaminophen. Patients in Group 2 were given $1 \mathrm{mg} \mathrm{kg}^{-1}$ of meperidine intramuscularly. Both medications were administered after the induction of anaesthesia.

Venous blood samples were drawn at $0,15,30,60,120$, 
TABLE I Pain evaluation scale

\begin{tabular}{lll}
\hline Cinicai observation & Criteria & Points \\
\hline Agitation & $\begin{array}{l}\text { Patient asleep or calm } \\
\text { Mild agitation } \\
\text { Uncontrollable }\end{array}$ & 2 \\
& $\begin{array}{l}\text { Not crying } \\
\text { Respond to tender loving } \\
\text { Crying }\end{array}$ & 0 \\
& $\begin{array}{l}\text { Crying and does not respond } \\
\text { to tender loving care }\end{array}$ & 2 \\
& $\begin{array}{l}\text { Asleep or no complaint } \\
\text { Cannot localise pain } \\
\text { Cain vertalisation }\end{array}$ & 0 \\
& Can localise pain & 1 \\
\hline
\end{tabular}

Adepted from Hannallah RS et al ; Anesthesiology 1984; 6: A-429

and 240 minutes after the administration of the analgesics through an heparinized catheter. Serum acetaminophen concentrations were determined by fluorescence polarization immunoassays with a TDx System (Abbot Laboratory, Toronto, Ontario). The coefficient of variation was estimated before each daily assay procedure with five control samples at $33.1,66.2$ and $99.3 \mu \mathrm{mol} \cdot \mathrm{L}^{-1}$ of acetaminophen. The coefficients of variation ranged from 1.3 per cent to 6.7 per cent.

The analgesic effect of the two medications was assessed by evaluating the intensity of pain based on three symptoms: pain, agitation, and crying (Table I) when the child awakened in the recovery room. ${ }^{7}$ This assessment was done by one of the authors who did not know which drug had been administered to the patient. We also looked for side effects such as central nervous system depression and vomiting. Vital signs were monitored continuously. When analgesia was considered insufficient by the medical personnel working in the recovery room a dose of meperidine $1 \mathrm{mg}^{-1} \mathrm{~kg}^{-1}$ intramuscularly was given to the child.

Statistical analyses were performed using the Mann Whitney $\mathrm{U}$ test and chi-square analysis. The results are presented with the mean and the standard deviation.

\section{Results}

The demographic parameters such as age, sex, weight and surgical procedures were not significantly different between the two groups and are presented in Table II.

The mean time that elapsed between the administration of the analgesic agent and the arrival of the patient in the recovery room was of $29.1 \pm 13.3$ minutes and $26.6 \pm$ 12.1 minutes in Group 1 and Group 2, respectively.

Acetaminophen mean senum concentrations obtained at $15,30,60,120$ and 240 minutes post administration were $22.5( \pm 10.6) \mu \mathrm{mol} \cdot \mathrm{L}^{-1}, 35.1( \pm 15.9) \mu \mathrm{mol} \cdot \mathrm{L}^{-1}, 64.9$
TABLE II Demographic parameters

\begin{tabular}{lll}
\hline Parameters & Group I & Group 2 \\
\hline Age (years) & $4.4( \pm 1.4)^{*}$ & $4.7( \pm 1.7)$ \\
Sex & & 11 \\
Malc & 14 & 9 \\
Female & 6 & $17.3( \pm 4.1)$ \\
Weight (kg) & $17.9( \pm 2.7)$ & \\
Type of surgery & & 8 \\
Adenoidectnmy & 8 & 0 \\
Tonsillextomy & 4 & 12 \\
Bath & 8 & \\
\hline
\end{tabular}

*Meạn and standard deviation.

$( \pm 23.17) \mu \mathrm{mol} \cdot \mathrm{L}^{-1}, 72.2( \pm 11.3) \mu \mathrm{mol} \cdot \mathrm{L}^{-1}$, and 43.7 $( \pm 7.9) \mu \mathrm{mol} \cdot \mathrm{L}^{-1}$ respectively (Figure I). Peak serum concentrations were achieved within 120 minutes.

Analgesia was considered unsatisfactory in 32 patients who required a dose of meperidine $\left(1 \mathrm{mg} \cdot \mathrm{kg}^{-1}\right)$ in the recovery room. All eight patients who did not require meperidine in the recovery room underwent an adenoidectomy and received a mean pain score of $5.8 \pm 0.5$. Six of these patients received meperidine at induction and two received acetaminophen. There is no significant difference between the two groups. The 32 patients who required meperidine in the recovery room had a mean score of $2.5 \pm 1.2(p<0.0001)$.

No serious side effects were noted during the course of the study. Pulse, blood pressure and respiratory rate remained in the normal range in both groups. Vomiting was experienced by seven patients ( 35 per cent) who received acetaminophen and nine patients ( 45 per cent) who received meperidine. Patients of both groups were fully awake four hours post surgery.

\section{Discussion}

This study demonstrates that the administration of a single dose of $20 \mathrm{mg} \cdot \mathrm{kg}^{-1}$ of acetaminophen intrarectally or 1 $\mathrm{mg} \cdot \mathrm{kg}^{-1}$ of meperidine intramuscularly during the induction of anaesthesia does not adequately prevent the occurrence of pain in the recovery room in children undergoing adeno-tonsillectomy. Several factors can explain this phenomenon.

Primarily, the low serum concentrations of acetaminophen $\left(35.1 \pm 15.9 \mu \mathrm{mol} \cdot \mathrm{L}^{-1}\right)$ we obtained when the child starts awakening ( 30 minutes post administration) are probably insufficient to produce analgesia. Although there is no correlation established betwen serum acetaminopher concentrations and the degree of analgesia produced in children, concentrations between 66.2 and $132.4 \mu \mathrm{mol} \cdot \mathrm{L}^{-1}$ are necessary to obtain an adequate antipyretic effect. ${ }^{3.8}$ The low concentrations we obtained were probably the result of incomplete absorption. Previ- 


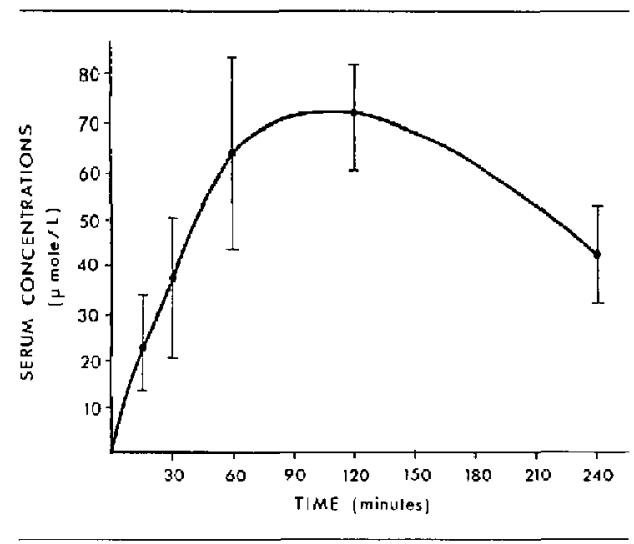

FIGURE Serum concentrations (mean \pm SD) obtained after the rectal administration of an aquous solution of acetaminophen $\left(20 \mathrm{mg} \cdot \mathrm{kg}^{-1}\right)$ in children.

ous studies have demonstrated that serum concentrations of $130.4 \pm 30.5 \mu \mathrm{mol} \cdot \mathrm{L}^{-1}$ can be achieved when 20 $\mathrm{mg} \cdot \mathrm{kg}^{-1}$ of an acetaminophen solution is administered orally. ${ }^{9}$ Our study has also demonstrated that the absorption can be delayed. The peak serum concentration was achieved only at 120 minutes in ten of our patients ( 50 per cent)

Following oral administration of actaminophen the peak concentration is usually achieved in 30 minutes. 3,9 In contrast, to another study our results demonstrate that the rectal administration of an aqueous solution of acetaminophen during the induction of anaesthesia is not comparable to its oral administration. ${ }^{2,9}$ Possible changes in the distribution of the blood flow to the colon during anaesthesia may be responsible for the low serum concentrations we obtained and the delayed absorption.

Secondly, the absence of an adequate analgesia in the patient having received acelaminophen could be related to the fact that this medication is not potent enough to surb the pain associated with an adeno-tonsillectomy. However, the low concentrations we obtained after 30 minutes restrain us from making firm conclusions concerning the potency of acetaminophen in the treatment of such pain.

Thirdly, the evaluation of pain in children is very difficult. The criteria we used are not specific. Indeed, cries and agitation can be the result of fear, anxiety or separation from their parents as well as the result of pain itself.

The absence of efficacy of meperidine is more surprising. It is possible that meperidine was not absorbed properly, secondary to the reduction of the blood flow in the muscle induced by halothane two per cent. ${ }^{10}$

In conclusion, the administration of $20 \mathrm{mg} \cdot \mathrm{kg}^{-1}$ of acetaminophen intrarectally or $1 \mathrm{mg} \cdot \mathrm{kg}^{-1}$ of meperidine intramuscularly, during the induction of anaesthesia does not adequately prevent the appearance of immediate post-operative pain in children undergoing an adenotonsillectomy. Furthermore the rectal administration of $20 \mathrm{mg} \cdot \mathrm{kg}^{-1}$ of an aqueous solution of acctaminophen at the time of induction of anaesthesia results in low and delayed peak serum concentrations.

\section{References}

1 Maron JJ, Ickes AC. The antipyretic effectiveness of acetaminophen suppositories versus tablets: a double blind study. Curr Ther Res 1967; 20: 45-52.

2 Moolenuar $F$, Dlthof L, Huiziga $T$. Absorptinn rate and bioavailability of paracetamol from aqueous suspen sions. Pharm Weeklab Scient. Ed. 1979; 1: 25-30.

3 Goodman and Gilman's. The pharmacological basis of therapeutics. Gilman AG, Goodman LS, Rall TW, Murad F (Eds). Macmillan Publish: New York, 1985.

4 Mehlisch DR, Frakes LA. A controlled comparative evaluation of acetaminophen and aspirin in the trcatment of postoperative pain. Clin Ther 1984; 7: 89-97.

5 Seymour RA. Efficacy of paracetamol in reducing post operative pain after periodontal surgery. J Clin Periodontol 1983; 10: 311-6.

6 Tigerstedt $I$, Leander $P$, Tammisro $T$. Postoperative analgesics for superficial surgery. Comparison of four analgesics. Acta Anaesthesiol Scand 1981; 25: 243-7.

7 Hannallah RS, Broadman LM, Belman AB, Abramovitz $M D$, Epstein BS. Control of post-orchiopexy pain in pediatric outpaticnts: comparison of two regional techniques. [Abstract] Anesthesiology, 1984; 61: A429.

8 Rumack BH. Aspirin versus acetaminophen: A comparative view. Pediatrics 1978; 62: 943-6.

9 Windofer $A$, Vogel $C$. Investigations concerning serum concentration and temperature following oral application of a new paracetamol preparation. Klin Paediatr 1976; 188: 430-4.

10 Eger II EI, Smih NT, Staelting RK, Cullen DS, Kadis $L B$, Whitcher $C E$. Cardiovascular effects of halothane in man, Anesthesiology 1970; 32: 396-409. 


\section{Résumé}

L'acétaminophène est un médicament fréquemment utilisế en péditurie pour ses propriétés unalgésiques quevique son efficacité n'est pas êté bien étudie dans cette population. Dans certaines situations cliniques, telles les vomissements et l'inconscience, tes médicaments doivent êrre administrés par voie rectale. Toulefois il est bien connnu que l'absorptian des suppositoires est souvent erratique. C' «st pourquoi nous uvons étudié l'absorption rectale d'une solution aqueuse d'acétaminophène. De plus, nous avons comparé son effet analgésique à celui de la méperidine chez 40 enfants ages de un d huit ans admis pour adêno-amygdaiectomie. Au moment de l'induction anesthésique, 20 patients ont reçu $20 \mathrm{mg} \cdot \mathrm{kg}^{-I}$ d' acétaminophène intrarectal alors que les autres ont reģu $1 \mathrm{mg} \cdot \mathrm{kg}^{-1}$ de mépéridine intra-musculaire. L'analgésie post-opératoire s'est avérée insuffisante chez 32 patients (acétaminophène: 18, mépéridine: 14). L'absorption de l'acétaminophène a été incomplète (concentration sérique maximale: $70.8 \mu \mathrm{mol} \cdot \mathrm{L}^{-1}$ ) et retardée. En conclusion, l'administration intra-rectale d'acétaminophène au moment de l'induction anesthésique ne procure pas une analgésie post-opératoire adéquate et entraine une absorption incomplète el resardée. 